\title{
Ophryotrocba labronica as test animal for the study of marine pollution
}

\author{
B. ÅKESSON \\ Zoological Institute; Lund, Sweden
}

\begin{abstract}
KURZFASSUNG: Opbryotrocba labronica als Versuchstier für das Studium mariner Wasserverunreinigung. Der Polychaet Ophryotrocha labronica hat sich als geeignetes Testobjekt für Untersuchungen über Probleme der Verunreinigung von Meeresgebieten erwiesen. Als Kriterien für derartige Untersuchungen können herangezogen werden: Wachstumsgeschwindigkeit, Reproduktionsleistung, Dauer der verschiedenen Entwicklungsstadien, Sterblichkeit sowie Beobadhtungen über Bewegungen und Nahrungsaufnahme. Die Größe des Polychaeten ïberschreitet kaum 4,5 mm. Er ist herbivor und kann in großer Anzahl in verhältnismäßig kleinen Gefäßen ganzjährig gezüchtet werden. Bei $20^{\circ} \mathrm{C}$ wird die Entwicklung in weniger als einem Monat abgeschlossen. Die Reproduktionsleistung ist sehr groß. Pro Weibchen werden durchschnittlich 120 Nachkommen produziert. Die Züchtungsmethoden werden beschrieben und die Ergebnisse einiger Versuche über den Einfluß von Nahrung, Temperatur, Salzgehalt sowie von industriellen Abfallstoffen (Schwefelsäure, Äthylenglykol) mitgeteilt.
\end{abstract}

\section{INTRODUCTION}

In the study of marine pollution a wide variety of test animals has been used. As it is generally accepted that embryos and larvae constitute the most sensitive stages of the life cycle, the use of larvae is preferred in many experiments (CORNER et al. 1968, WiLson 1968). However, in all these pollution studies (even those dealing with experiments on long-term effects of different polluters) only part of the life cycle is employed in a single experiment. Therefore, another type of test animal is required, where the experiments can be extended over the whole life cycle. This does not mean that the new test animals should replace established ones which are often of special interest because of their commercial value. They should be used in parallel experiments. If one or several of these new test animals could be put to world-wide use the comparison of results from different experiments would be facilitated.

I am proposing Ophryotrocha labronica as test animal because this little polychaete meets many important requirements of a good test animal, both for marine pollution research and for ecological studies in general. Some of the more important qualities are listed below:

(1) Opbryotrocha labronica is easy and cheap to cultivate. A culture can be maintained for years in a laboratory. (2) The culture provides material for experiments all 
year round. (3) The small size of the animals - the maximum length recorded is $4.9 \mathrm{~mm}$ - facilitates space-saving cultivation and experiments. (4) O. labronica is herbivorous and thrives well in crowded populations. (5) Its reproductive capacity is enormous. Experiments can be performed with either the larvae of a single egg mass or a larval population obtained by synchronizing the egg-laying of a number of females. In my experiments I have often been working with populations large enough to provide material for a statistical analysis. (6) It is possible to extend experiments over a complete life cycle. At room temperature (about $20^{\circ} \mathrm{C}$ ) the life cycle is completed within 4 weeks. The average number of eggs produced is 120 . A female can lay eggs every second week for at least 3 months. (7) Growth rate, reproductive capacity, duration of different life cycle stages, and the rate of survival represent useful parameters. (8) The animals can be transported easily between laboratories; they survive for several days in a closed thermos.

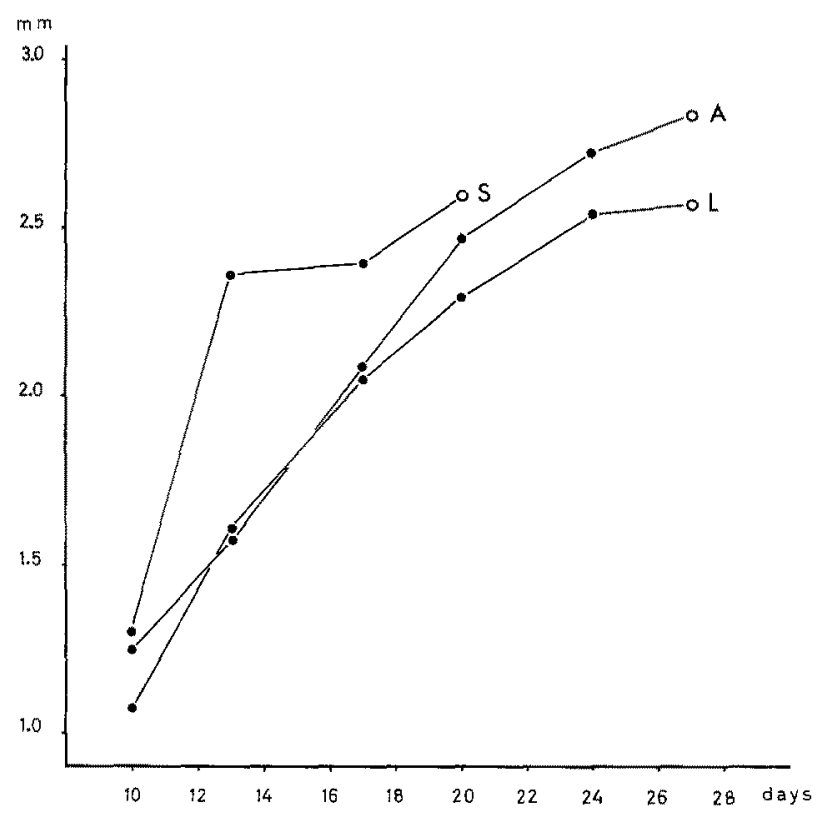

Fig. 1: Opbryotrocha labronica. Growth rate and time span from hatching to spawning with 3 types of food. S: powder made from frozen, dried spinach; A: powder made from Ulva and Enteromorpha; L: powder made from lettuce leaves. Open circles indicate the presence of egg masses

\section{CULTIVATION}

My original strain of Ophryotrocha labronica was collected in Naples during the winter of 1965. It has now been kept for more than 50 generations. There have been no signs of decreased vitality. In June, 1969, a new strain was collected in Leg- 
horn. O. labronica was originally described from Leghorn (LA GRECA \& BACCI 1962).

Stock cultures are kept in aquaria of 3-5 1 volume at room temperature or (in order to slow down reproduction rate) at $15^{\circ} \mathrm{C}$. When the aquaria become overpopulated the majority of animals must be discarded.

The experiments are performed in covered bowls with a volume of 15 and $80 \mathrm{ml}$, respectively. The water is changed once or twice a week; its salinity ranges between 32 and $34 \%$. The water is filtered and sterilized by heating to $80^{\circ}-90^{\circ} \mathrm{C}$.

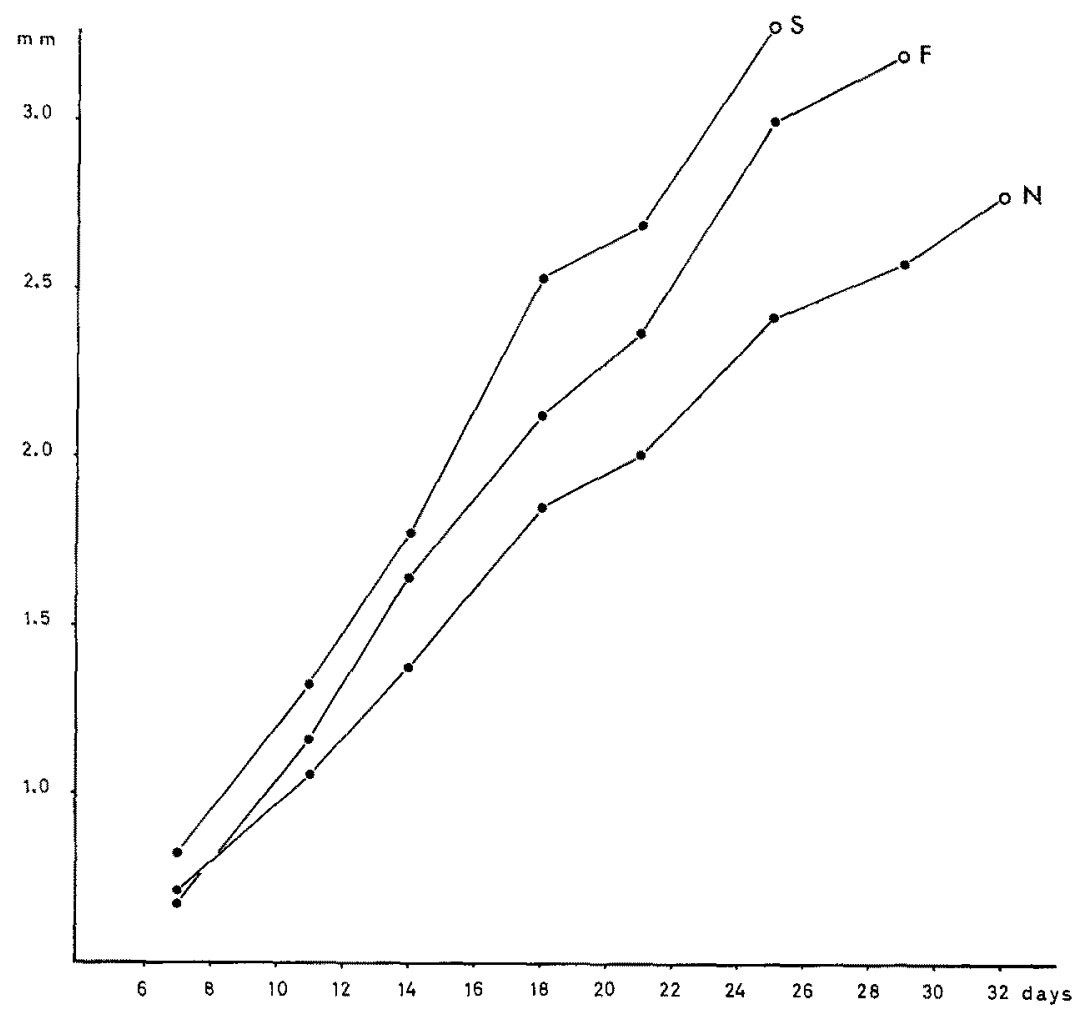

Fig. 2: Opbryotrocha labronica. Growth rate and time span from hatching to spawning with 3 types of food. S: fragments scraped from a frozen blodk of spinach; F: a green flagellate; $\mathrm{N}$ : Nitzschia closterium. Open circles indicate the presence of egg masses

The polychaetes are fed with ordinary frozen spinach (according to the information on the cover of the package it is picked, washed, parboiled, and cut before freezing). Fragments are scraped from the surface of the frozen block and put into sea water, the water is then changed 3-4 times before the food is given to the worms.

In addition, larvae which have just hatched are usually offered a mixture of Nitzschia closterium and a green flagellate. It is possible, however, to start feeding with spinach at once. 


\section{FOOD, TEMPERATURE AND SALINITY}

Experiments under varying conditions of food, temperature and salinity always started with a population of newly hatched Opbryotrocha labronica larvae from a number of egg masses which had developed synchronously. In order to obtain synchronous development, mature females are isolated at $15^{\circ} \mathrm{C}$. After about a week they are returned to room temperature (about $20^{\circ} \mathrm{C}$ ) and males added to the bowls. Thereafter, most females deposit their egg masses within $12 \mathrm{~h}$.

\section{Food}

In a pilot study, living pieces of Ulva and Enteromorpha were given to the polychaetes, but they refused to eat them. When the algae were frozen and handled in the same way as spinach they were accepted as food and the test animals developed normally.

In another experiment, three types of food were compared. (1) Powder made from frozen and dried commercial spinach; (2) powder made from lettuce leaves; (3) powder made from frozen and dried Ulva and Enteromorpha.

An equal number of larvae, approximately 75, were placed in each of the 12 bowls, each type of food to 4 bowls. Once or twice a week the body length and the number of parapodia of 10 test animals in each bowl were recorded. The presence of egg masses was checked every day. The individuals to be measured were chosen at random. The mean of 40 measurements was plotted against time on a diagram (Fig. 1). All diagrams of growth rates are based on the same method. Spinach gives the best growth and earliest sexual maturity.

In a similar experiment, the nutritional value of frozen and scraped spinach was compared to that of the green flagellate and Nitzschia (Fig. 2). In these experiments the effect of each kind of food was studied in 4 bowls.

\section{Temperature}

The same methods can be used for assessing the effects of temperature. The following preliminary information is extracted from a manuscript, to be published separately. The optimum temperature of $26^{\circ} \mathrm{C}$ is very close to the maximum temperature. At $28^{\circ} \mathrm{C}$, growth is most rapid, reproduction almost normal, mortality during early embryogenesis increased. At $30^{\circ} \mathrm{C}$, growth is slower and the eggs do not develop. At $32^{\circ} \mathrm{C}$, both adults and larvae die within a week.

At $14^{\circ} \mathrm{C}$, reproduction is still possible, but the time span of a complete life cycle is almost 5 times that at $26^{\circ} \mathrm{C}$.

\section{Salinity}

In addition to growth rate and reproductive ability, the rate of survival may provide information about the salinity tolerance. Opbryotrocha labronica is euryhaline. 


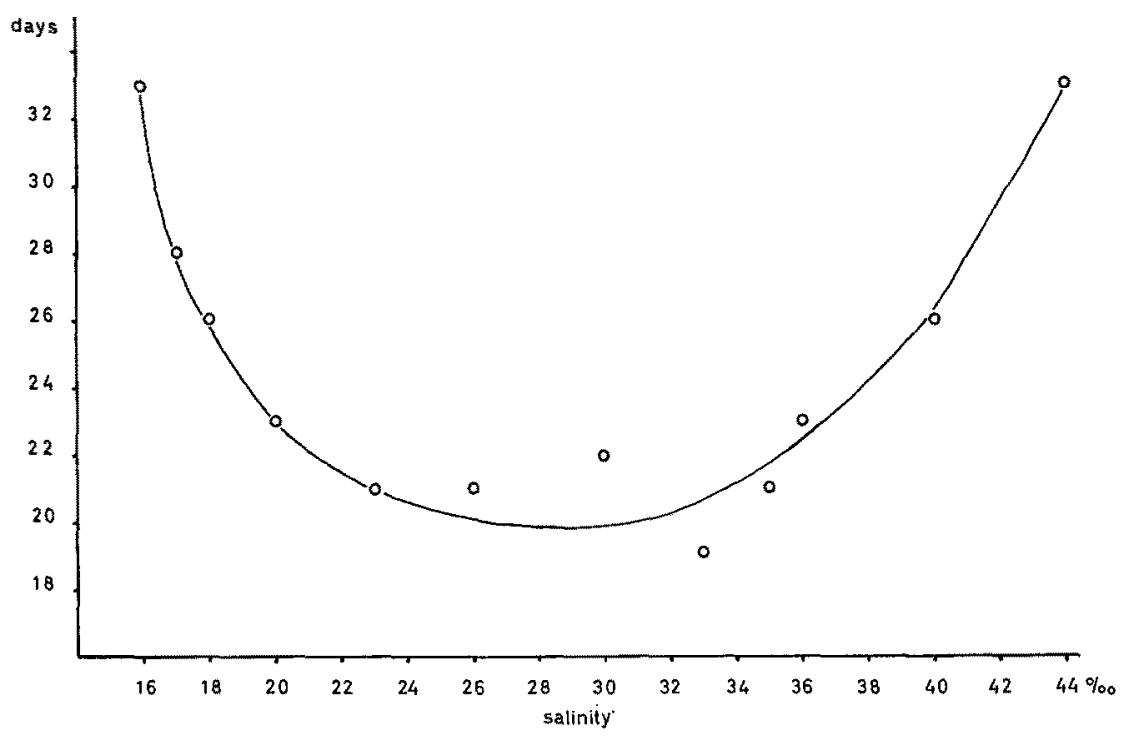

Fig. 3: Opbryotrocha labronica. Time from hatching to spawning in different salinities. Average values of 4 experiments

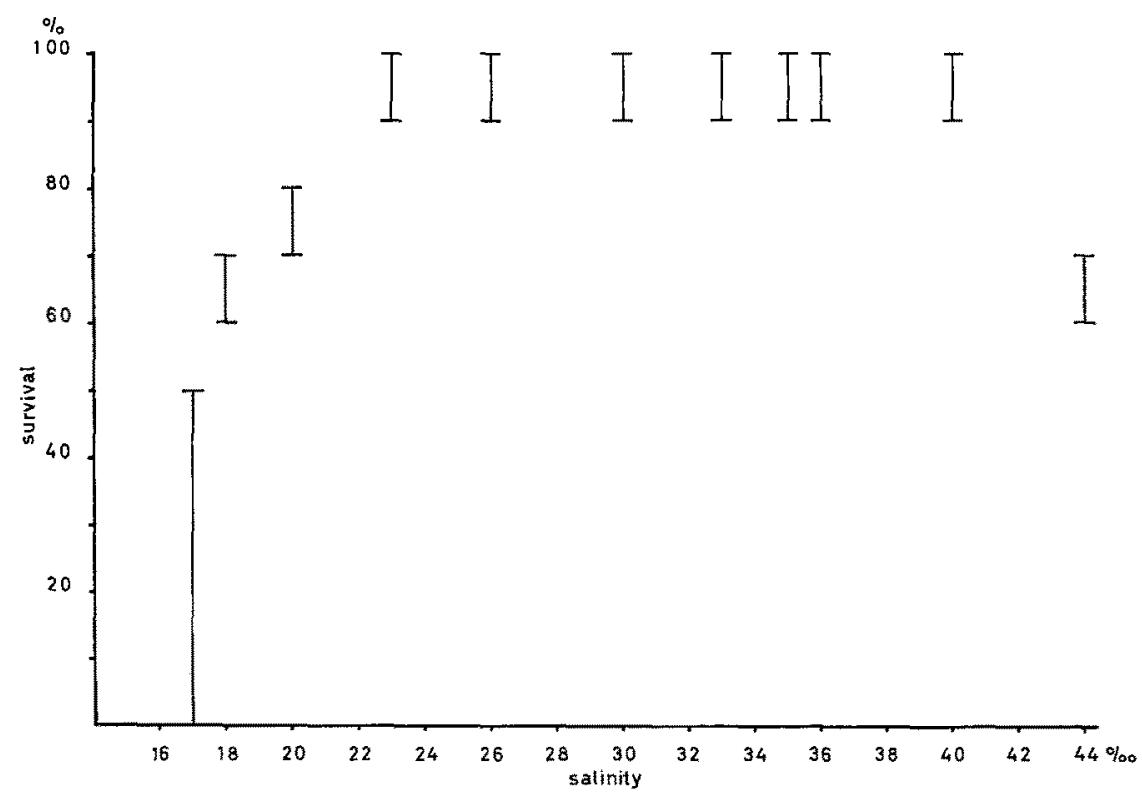

Fig. 4: Ophryotrocha labronica. Estimated rate of successful development in different salinities. Average values of 4 experiments. At $16 \% \mathrm{~S}$ no development occurred 
Between 23 and $40 \% \mathrm{~S}$ the life cycle is quite normal. In a salinity of $44 \% \mathrm{~S}$, adults may survive for several weeks and even reproduce, but the developmental rate of the egg masses decreases from $90-100 \%$ to about $60-70 \%$. The development of surviving larvae is slow but quite normal. In a salinity of $48 \%$, adults die within 10 days. If egg masses are produced they are abnormal and no development occurs.

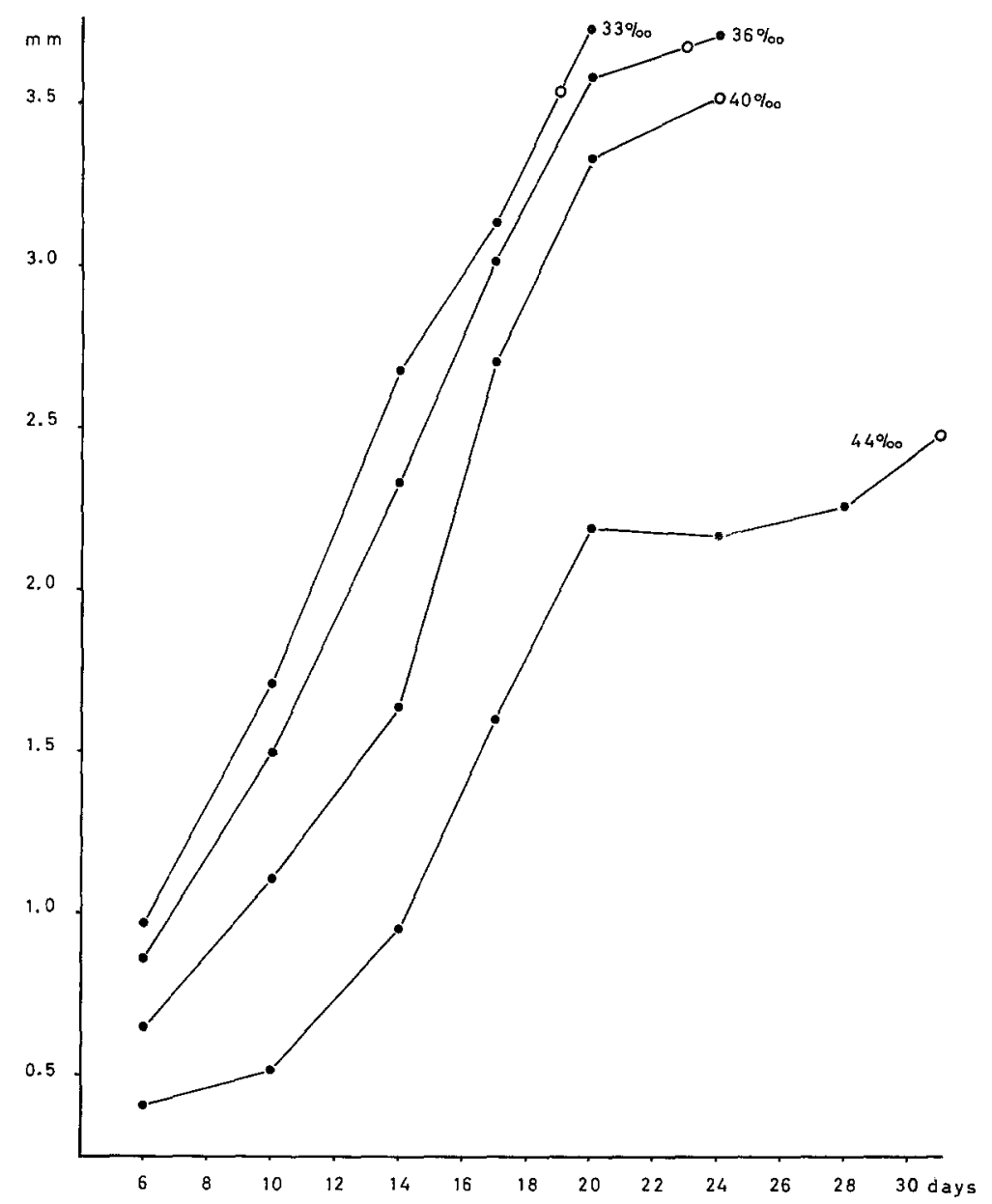

Fig. 5: Ophryotrocha labronica. Growth rate and time span from hatching to spawning in 4 different salinities. Open circles indicate the presence of egg masses

In low salinities, young larvae can grow, become sexually mature and produce egg masses down to $16 \% \mathrm{~S}$ (Fig. 3). These eggs do not develop. At $17 \%$ S $\mathrm{S}$ the rate of successful development varies between $\mathrm{O}$ and $50 \%$; at $18 \% \mathrm{~S}$ between $60-70 \%$; and at $20 \% \mathrm{~S}$ it amounts to about $80 \%$ (Fig. 4).

Judging from the growth rate and the time span necessary to produce the first egg masses, the salinity optimum is $33 \%$ (Fig. 5). However, this statement could be 
erroneous as the stock of polychaetes used in the experiments had been cultivated for about 40 generations in sea water of $33 \%$ salinity. During such a high number of generations a selection is quite possible.

\section{POLLUTED WATERS}

\section{Sulphuric acid}

Sulphuric acid is sometimes discharged by chemical industries. Increased concentrations slow down the growth rates (Fig. 6). The reproduction remains quite normal up to $40 \mathrm{ppm}$. Even at 50 and $60 \mathrm{ppm}$ larvae can grow, become sexually mature and

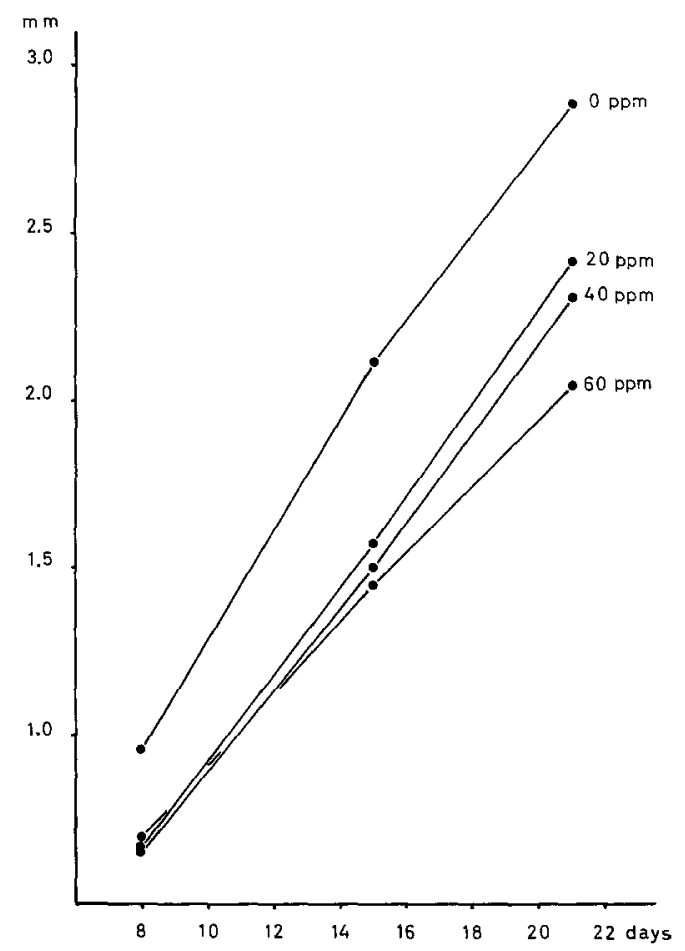

Fig. 6: Ophryotrocha labronica. Growth rate at different concentrations of $\mathrm{H}_{2} \mathrm{SO}_{4}$

produce egg masses; but the mortality rates during early development increase to more than $50 \%$. At $65 \mathrm{ppm}$ larvae die within $6 \mathrm{~h}$, adults within 3 days. At $70 \mathrm{ppm}$ both larvae and adults die within $2 \mathrm{~h}$. The narrow range between lethal and non-lethal concentrations can be related to the buffering capacity of sea water, which is effective up to about $60 \mathrm{ppm}$ (Fig. 7). 


\section{Ethylene glycol}

This pollutant is excellent for the demonstration of differences between shortterm and long-term effects. Both adults and larvae can survive for several days at a

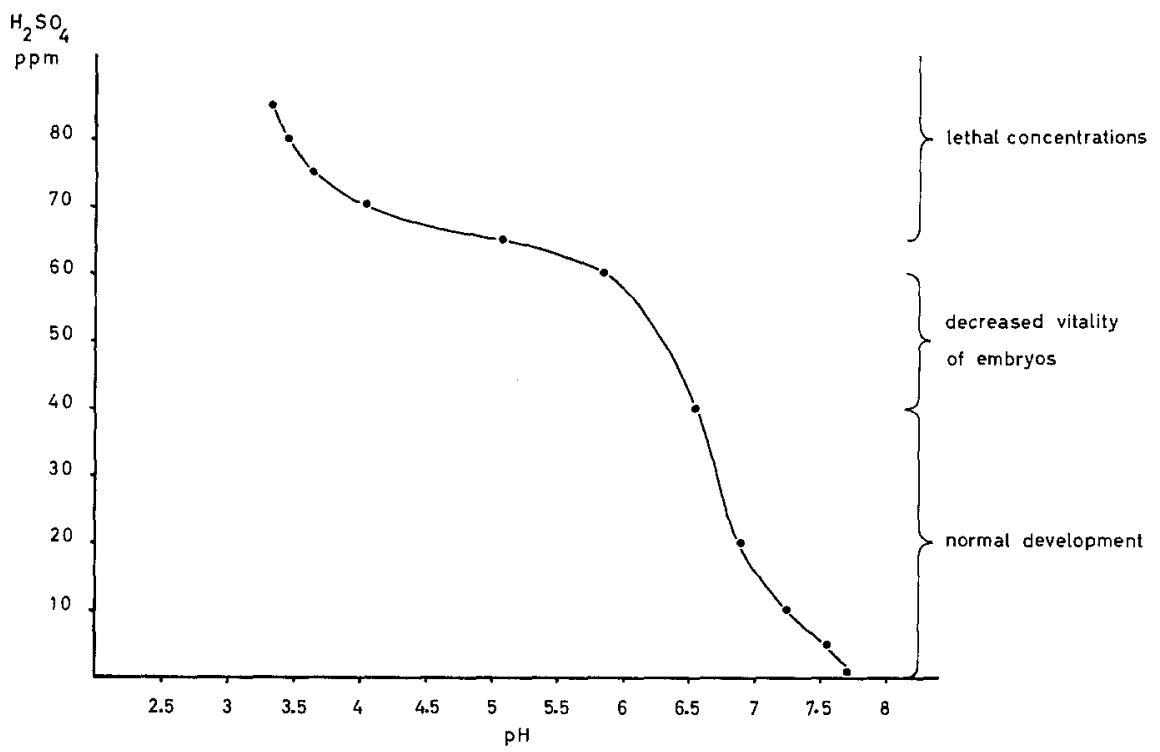

Fig. 7: Ophryotrocha labronica. Different concentrations of $\mathrm{H}_{2} \mathrm{SO}_{4}$ related to $\mathrm{pH}$ and the vitality of the test individuals

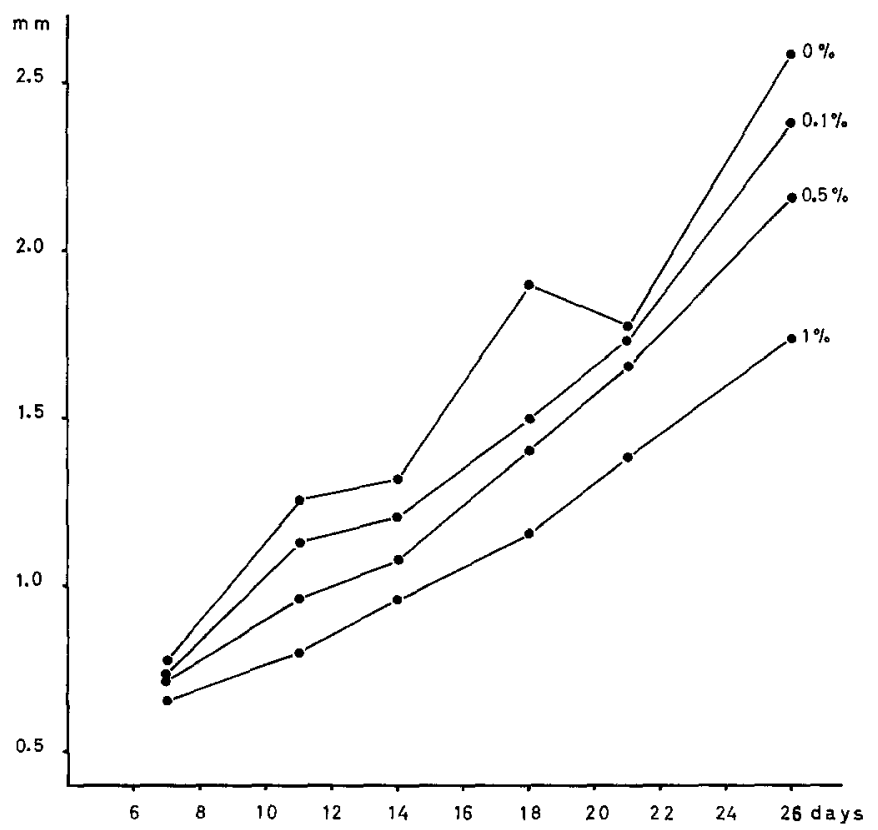

Fig. 8: Opbryotrocha labronica. Growth rate at different concentrations of ethylene glycol 
concentration of $5 \%$ ethylene glycol; after 7 days, about $10 \%$ of the larvae are still alive. At a concentration of $1 \%$, adults and larvae eat and behave quite normally, but $80-90 \%$ die within 2 weeks; after 4 weeks less than $5 \%$ are still alive.

Adult Opbryotrocha labronica are more hardy than larvae. In an experiment with adults the following percentages of survival were recorded after 40 days:

$\begin{array}{ccccc}500 \mathrm{ppm} & 100 \mathrm{ppm} & 50 \mathrm{ppm} & 10 \mathrm{ppm} & \text { Control } \\ 50 \% & 75 \% & 80 \% & >90 \% & >90 \%\end{array}$

In an experiment where the growth rate in low concentrations of ethylene glycol was recorded, the number of surviving individuals was counted at the end of a

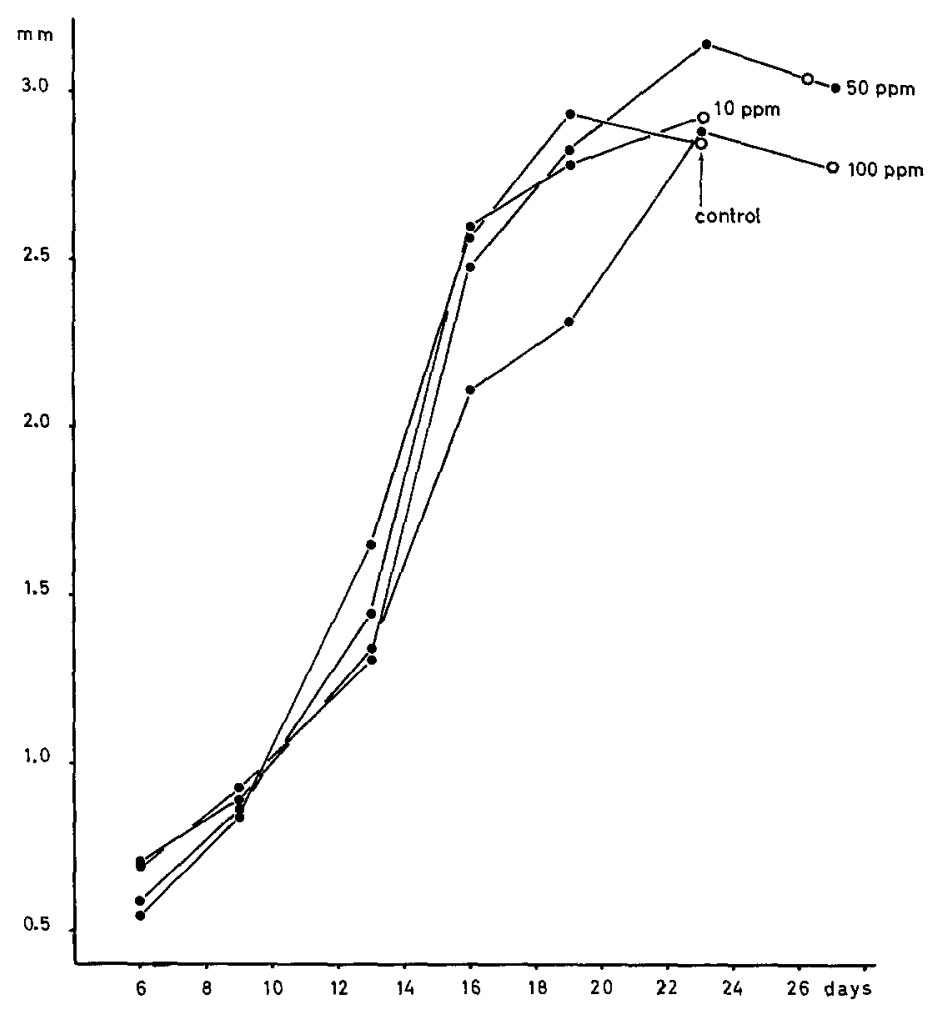

Fig. 9: Ophryotrocha labronica. Growth rate and time span from hatching to spawning at low concentrations of ethylene glycol. Open circles indicate the presence of egg masses

4-week period. The experiment had started with approximately the same number of larvae in all bowls (Tab. 1). Obviously, concentrations higher than $10 \mathrm{ppm}$ are harmful in this kind of long-term experiment.

The recorded rate of growth was as expected: the higher the concentration of ethylene glycol the slower the growth (Fig. 8). Results on changes in growth rate if combined with observations on survival and reproductive capacity, provide more precise information about the effects of pollutants. When the effects of low concen- 
trations of ethylene glycol are compared, growth rates remain approximately the same (Fig. 9), but the rate of survival may vary considerable (Tab. 1). Eggs produced in 100 and $50 \mathrm{ppm}$ do not develop.

Table 1

Opbryotrocha labronica. Number of surviving individuals after a 4-week exposure to different concentrations of ethylene glycol. The tests started with approximately the same number of larvae in each bowl

\begin{tabular}{|ccccc|}
\hline Bowl No. & \multicolumn{3}{c}{ Ethylene glycol concentrations (ppm) } \\
\hline 1 & 100 & 50 & 10 & Control \\
2 & 34 & 45 & 72 & 60 \\
3 & 32 & 43 & 65 & 86 \\
4 & 28 & 49 & 76 & 58 \\
\hline 2 & 47 & 58 & 64 & 78 \\
\hline
\end{tabular}

The experiments reported here and several others have convinced me that Opbryotrocha labronica has many of the requirements essential for becoming a test animal for assessing the biological consequences of marine pollutions. It is also an excellent laboratory animal for general use in class-room experiments.

\section{SUMMARY}

1. The polychaete Ophryotrocha labronica LA GRECA \& BACCI is proposed as test animal for marine pollution research. It also provides excellent material for classroom studies.

2. The size of O. labronica seldom exceeds $4.5 \mathrm{~mm}$; it is herbivorous and can be cultured in crowded populations in limited amounts of sea water. As it is possible to work at the population level, experimental results are easily available for statistical analysis.

3. Growth rate, ability to reproduce and the duration of different stages of the life cycle form convenient parameters. In addition, useful observations can be made on locomotion, feeding and mortality.

4. All life cycle stages are available for experiments throughout the year. At $20^{\circ} \mathrm{C}$, the whole life cycle is completed in less than 1 month.

5. The reproductive capacity is enormous. A female produces an average progeny of 120 and may repeat egg laying every second week for at least 3 months. The reproduction cycles of females can be synchronized yielding large populations of equal sized young larvae.

6. Cultivation methods are described, as weil as experiments conducted under varying conditions of nutrition, temperature and salinity.

7. The effects of pollutants (ethylene glycol, sulphuric acid) on different life processes are considered. 


\section{LITERATURE CITED}

Corner, E. D. S., Southward, A. J. \& Southward, E. C., 1968. Toxicity of oil-spill removers ('detergents') to marine life: an assessment using the intertidal barnacle Elminius modestus. J. mar. biol. Ass. U. K. 48, 29-48.

LA GRECA, M. \& BACCI, G., 1962. Una nuova specie di Ophryotrocha delle coste tirreniche (Annelida, Polychaeta). Boll. Zool. 29, 7-18.

WiLson, D. P., 1968. Long-term effects of low concentrations of an oil-spill remover ('detergent'): tests with larvae of Sabellaria spinulosa. J. mar. biol. Ass. U. K. 48, 177-182.

Author's address: Dr. B. Åkesson

Zoological Institute

Helgonavägen 3

Lund, Sweden 